\title{
EFFECTS OF CYCLIC EXPANSION-EXTRUSION WITH AN ASYMMETRICAL EXTRUSION CAVITY (CEE-AEC) ON THE MICROSTRUCTURE AND TEXTURE EVOLUTION OF Mg-13Gd-4Y-2Zn-0.5Zr ALLOYS
}

\author{
VPLIV POSTOPKA CIKLIČNE EKSPANZIJSKE EKSTRUZIJE Z \\ ASIMETRIČNO EKSTRUZIJSKO VOTLINO NA \\ MIKROSTRUKTURO IN RAZVOJ TEKSTURE \\ Mg-13Gd-4Y-2Zn-0,5Zr ZLITINE
}

\author{
Hongzhi Fan, Zhaoming Yan, Zhimin Zhang, Qiang Wang, Jian Xu, Yong Xue* \\ School of Materials Science and Engineering, North University of China, No. 3 Xueyuan Rd., Taiyuan 030051, China
}

Prejem rokopisa - received: 2019-10-17; sprejem za objavo - accepted for publication: 2020-02-27

\author{
doi:10.17222/mit.2019.251
}

The effect of the passes of cyclic expansion-extrusion with an asymmetrical extrusion cavity (CEE-AEC) on the microstructure and texture evolution of the Mg-13Gd-4Y-2Zn-0.5Zr $(w / \%)$ alloy was investigated in this research. The alloy was subjected to $(1,2,3$ and 4) passes at $(753,733,723$ and 693) K, respectively. An optical microscope (OM), a scanning electron microscope (SEM) and electron backscattered diffraction (EBSD) were used to study the microstructure and texture evolution. The CEE-AEC process caused a significant grain refinement as the grain size decreased to $1.4 \mu \mathrm{m}$ from the initial value of $24 \mu \mathrm{m}$ after three CEE-AEC passes, while it increased slightly, to $1.6 \mu \mathrm{m}$, after an additional CEE-AEC pass. With the increasing of the CEE-AEC passes, the number fraction (NF) of low-angle grain boundaries (LAGBs) tended to decrease, and the average misorientation increased due to the enhancement of recrystallization. The basal texture was weakened after four CEE-AEC passes, and the shear strain led to a rotation by $45^{\circ}$. The maximum intensity was reduced from 11.692 to 1.944 .

Keywords: Mg-Gd-Y-Zn-Zr alloy, CEE-AEC, microstructure, texture

V članku avtorji opisujejo raziskavo vpliva posameznih prehodov skozi orodje pri postopku ciklične ekspanzijske ekstruzije z asimetrično ekstruzijsko votlino (CEE-AEC) na mikrostrukturo in razvoj teksture zlitine Mg-13Gd-4Y-2Zn-0,5Zr (v mas. \%). Zlitino so opazovali po prvem, drugem, tretjem in četrtem prehodu pri temperaturah ekstruzije $753 \mathrm{~K}, 733 \mathrm{~K}, 723 \mathrm{~K}$ in $693 \mathrm{~K}$. Z optičnim (OM) in vrstičnim elektronskim mikroskopom (SEM) ter s tehniko sipanja povratnih elektronov (EBSD) so študirali mikrostrukturo in razvoj teksture. S postopkom ciklične ekspanzijske ekstruzije z asimetrično ekstruzijsko votlino so dosegli pomembno udrobljenje (zmanjšanje velikosti) kristalnih zrn z začetnih $24 \mu \mathrm{m}$ na $1,4 \mu \mathrm{m}$ po treh prehodih, medtem ko je po dodatnem četrtem prehodu velikost kristalnih zrn narasla nazaj na 1,6 $\mu \mathrm{m}$. S povečevanjem števila prehodov CEE-AEC postopka se je delež malokotnih kristalnih mej zmanjševal in njihova povprečna dezorientacija se je povečala zaradi povečanja obsega rekristalizacije. Osnovna tekstura je bila oslabljena po štirih prehodih CEE-AEC postopka in zaradi strižne deformacije je prišlo do rotacije za $45^{\circ}$. Maksimalna intenziteta se je zmanjšala z 11,692 na 1,944.

Ključne besede: Mg-Gd-Y-Zn-Zr zlitina, ciklično-ekspanzijska ekstruzija z asimetrično ekstruzijsko votlino, mikrostruktura, tekstura

\section{INTRODUCTION}

Magnesium alloy is the lightest structural metal and it is the best material for lightweight transportation, aerospace and weaponry due to the low density, high specific strength, high specific stiffness along with excellent machinability and damping capacity. ${ }^{1}$ However, the hexagonal close-packed (hcp) crystal structure of a magnesium alloy results in poor ductility and formability at room temperature (RT). ${ }^{2}$ Severe plastic deformation (SPD) is considered to be an effective way for achieving grain refinement. ${ }^{3-7}$ Many investigations were carried out to study a variety of SPD processes, such as cyclic expansion-extrusion (CEE), ${ }^{8,9}$ equal channel angular

*Corresponding author's e-mail: yongxue395@163.com (Yong Xue) pressing (ECAP), ${ }^{10,11}$ large strain rolling $(\mathrm{LSR})^{12}$ and differential speed rolling (DSR). ${ }^{13}$

Cyclic expansion-extrusion (CEE), a new SPD technique, with which we can create a nano-scale-microstructure magnesium alloy, has been used to improve the strength and ductility of magnesium alloys by refining the grain size. CEE can accumulate strain and refine grains through a dynamic recrystallization. With its development and maturity, the CEE technology has been gradually applied to the AZ91 magnesium alloys ${ }^{14}$ and AA1050 aluminum alloys. ${ }^{15}$ CEE was developed by N. Pardis et al., ${ }^{8}$ based on cyclic extrusion compression (CEC) to study the microstructure and mechanical properties of aluminum-alloy bars. A. Babaei et al. ${ }^{14}$ studied the effect of $\mathrm{CEE}$ on the microstructure and properties of an AZ91 magnesium alloy tube. After two deformation passes, the grain size reached about $1 \mu \mathrm{m}$ 
and the elongation increased from $1.6 \%$ to $8.1 \%$. N. Pardis et al. ${ }^{15}$ studied the evolution of the microstructure and texture of the AA1050 aluminum alloy after the CEE deformation. The results showed that the grain size and texture of the sample reach a stable state after eight passes of the CEE process. Y. Xue et al. ${ }^{9}$ investigated the AZ80 alloy processed with CEE and the results showed that the grain size refined from $190 \mu \mathrm{m}$ to approximately $3 \mu \mathrm{m}$. Furthermore, CEE is better than ECAP in terms of grain refinement at the same accumulation of strain.

The present research is based on CEE, namely cyclic expansion-extrusion with an asymmetrical extrusion cavity at differential temperatures (CEE-AEC) and aims to evaluate the effects of CEE-AEC on the microstructure and texture evolution of $\mathrm{Mg}-13 \mathrm{Gd}-4 \mathrm{Y}-2 \mathrm{Zn}-0.5 \mathrm{Zr}$ alloys.

\section{EXPERIMENTAL PART}

In this study, the as-received Mg-13Gd-4Y-2Zn-0.5Zr magnesium alloy with the chemical composition from Table 1 was used. Rectangular billets of (250 (length) $\times$ 50 (width) $\times 100) \mathrm{mm}$ (thickness) were machined from extrusion bars for the CEE-AEC processing. A CEE-AEC die was designed and manufactured from the $3 \mathrm{Gr} 2 \mathrm{~W} 8 \mathrm{~V}$ tool steel, as shown in Figure 1. As the figure shows, the die consists of three cavities (the upper cavity, the lower cavity and the intermediate cavity). The size of the upper cavity and lower cavity is $100 \times 50 \mathrm{~mm}$ and the middle cavity is $100 \times 100 \mathrm{~mm}$.

Table 1: Chemical composition of a Mg-Gd-Y-Zn-Zr billet (w/\%)

\begin{tabular}{|c|c|c|c|c|c|c|c|}
\hline Element & $\mathrm{Gd}$ & $\mathrm{Y}$ & $\mathrm{Zn}$ & $\mathrm{Zr}$ & $\mathrm{Fe}$ & $\mathrm{Ni}$ & $\mathrm{Mg}$ \\
\hline Content & 12.8 & 4.0 & 1.8 & 0.42 & $\leq 0.001$ & $\leq 0.002$ & Bal. \\
\hline
\end{tabular}

The alloy was subjected to $(1,2,3$ and 4) passes at (753, 733, 723 and 693) K, respectively. Graphite was used as the lubricant to reduce the friction between the die and the specimen. For all the passes of the CEE-AEC tests, the constant ram speed was set to $1 \mathrm{~mm} / \mathrm{s}$. Each specimen was extruded from the die by pressing the next specimen and this was followed by air quenching.

After CEE-AEC, the samples were cut in the crosssectional plane perpendicular to the pressing direction. Metallographic samples were etched with a solution of $4.2 \mathrm{~g}$ of picric acid, $10 \mathrm{~mL}$ of acetic acid, $10 \mathrm{~mL}$ of distilled $\mathrm{H}_{2} \mathrm{O}$ and $70 \mathrm{~mL}$ of ethanol. Then the microstructure of the samples was characterized with an Axio Observer A2m Carl Zeiss optical microscope. The phase morphology and texture evolution were investigated with Hitachi SU5000 electron back-scattered diffraction (EBSD).

\section{RESULTS AND DISCUSSION}

\subsection{Microstructural characterization}

Figure 2 presents the optical micrograph of the as-received Mg-13Gd-4Y-2Zn-0.5Zr alloy. It was found that the as-received alloy whose microstructure and phase distribution were heterogeneous, consisted of coarse deformed grains, intragranular fine-lamellar LPSO phases, interdendritic block-shaped LPSO phases and a minimal amount of RE-rich phases. ${ }^{16,17}$ In general, the microstructure and phase distribution were heterogeneous, and the average grain size was calculated, with the linear intercept method, to be $24 \mu \mathrm{m}$.

OM micrographs of the Mg-13Gd-4Y-2Zn-0.5Zr alloy after (1, 2, 3 and 4) passes are presented in Figure 3. After $1 \mathrm{CEE}-\mathrm{AEC}$ pass at $753 \mathrm{~K}$, the grain orientation becomes ordered and the grains are refined (Figure 3a). The original coarse grains are deformed and elongated along the extrusion direction. Many fine grains are formed along the grain boundaries of coarse grains resulting in a 'necklace' structure due to DRX. Many fine-lamellar LPSO phases appear in the interior of the original coarse grains, and some net-like LPSO phases and fiber-like LPSO phases are distributed around the grains. ${ }^{18}$ The discovery of the typical bimodal distribution of the microstructure and the nucleation of fine grains at the original coarse grain boundaries indicate that DRX occurred after $1 \mathrm{CEE}-\mathrm{AEC}$ pass.
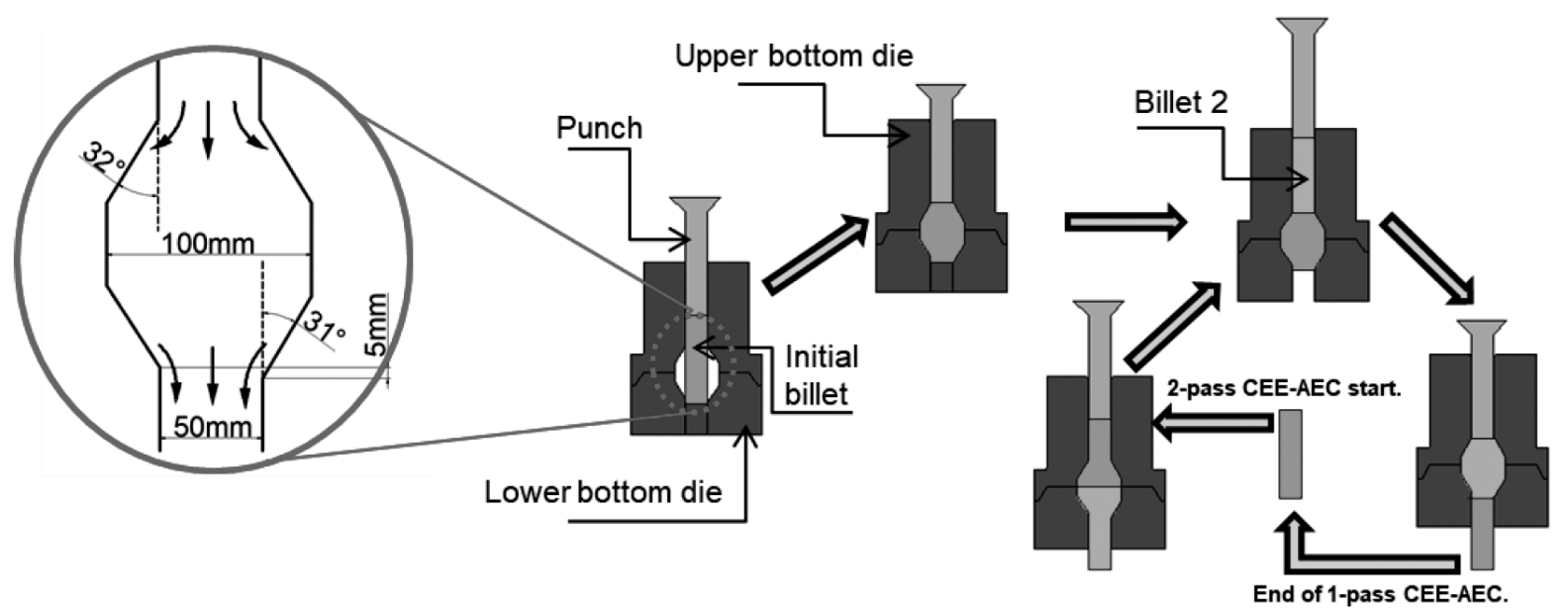

Figure 1: Schematic diagram of the CEE-AEC die and the forming principle used in the study 


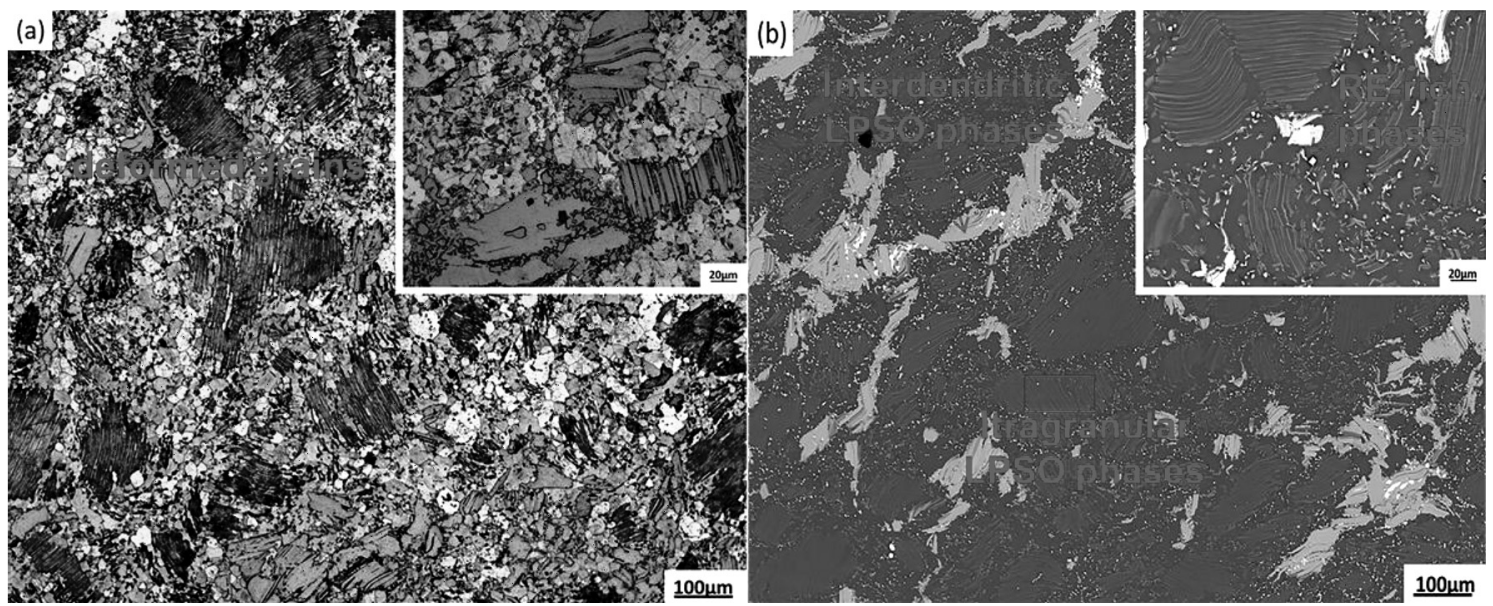

Figure 2: OM micrograph and BSE image of the as-received Mg-13Gd-4Y-2Zn-0.5Zr alloy

With the increase of the CEE-AEC process, the grains are continuously refined, and the microstructure becomes more homogeneous. Moreover, only a small number of the original coarse grains existed after 3 passes, and the grains are finer, equiaxed and uniformly distributed. Meanwhile, the degree of grain refinement continues to increase. The average grain size after $(1,2$, 3 and 4$)$ passes is $(17.8,8.3,1.4$ and 1.6) $\mu \mathrm{m}$, respect- ively. The thermal deformation promotes the precipitation of the fine-lamellar LPSO phase in the grain. This phase is deformed due to the rotation of the grains. With the increasing number of the CEE-AEC passes, the DRX region gradually expands, the size of the precipitated phase becomes smaller and its shape is more regular. In some grains, kink bands are generated due to the lamination of the LPSO phase. The intragranular LPSO
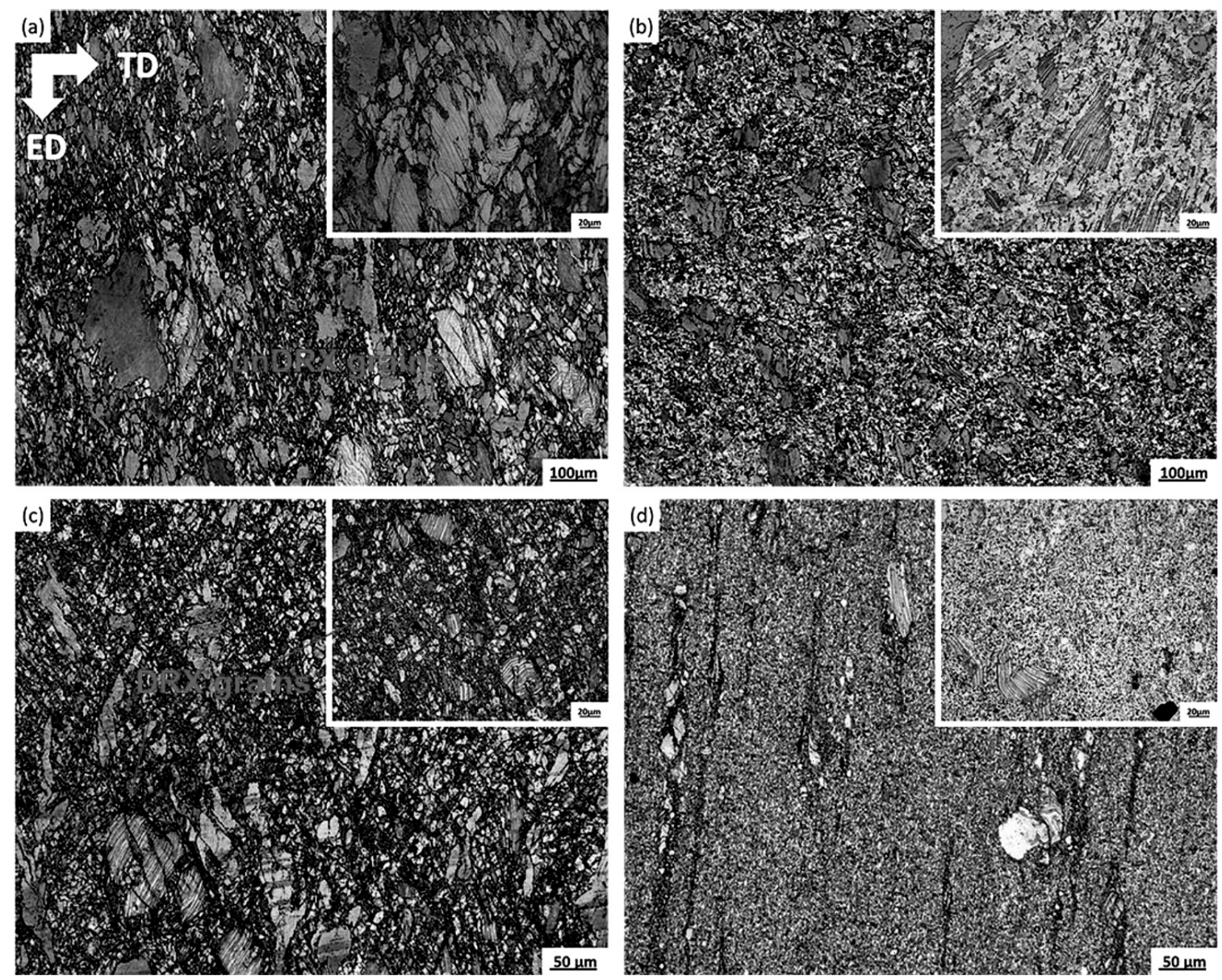

Figure 3: Optical-micrograph images of the alloys after different processing passes: a) 1 pass, b) 2 passes, c) 3 passes, d) 4 passes 
phases in different grains show different alignment directions, which generally show the tendency to align with the extrusion direction at 45 degrees. Moreover, the block-shaped phase is continuously sheared and broken into small pieces, and the initial $\alpha-\mathrm{Mg}$ grains are simultaneously broken during the CEE-AEC processes. In addition, after four passes of deformation, some fine, short, rod-like precipitates are found in the grains of the alloy (see the oval area in Figure 4d). These precipitates are shorter and thinner than the broken flakes and may form during the CEE-AEC process; they are similar to metastable LPSO phases or stacking faults. ${ }^{19}$

At the same time, due to the rotation of the grains during the deformation, DRX occurs, and the LPSO phase in the grains dissolves into the matrix. Due to the gradual increase of the dynamically recrystallized grains and the kink band of the block LPSO phase, a large number of $\mathrm{Mg}_{5}(\mathrm{Gd}, \mathrm{Y}, \mathrm{Zn})$ phases are dynamical precipitated. ${ }^{16}$ The fine-particle-phase precipitation may occur due to the precipitation of a supersaturated solidsolution rare-earth element along with the LPSO phase and the matrix during the deformation process. With the increase in the CEE-AEC passes, the accumulated strain increases gradually and the loading direction changes alternately between the axial direction and radial direction. The bulk LPSO phase is locally deformed and the kink deformation zone is gradually increased. In the block-shaped LPSO phase, it is shredded into a large number of short rods of about 2-5 $\mu \mathrm{m}$ and these short rods are distributed, in the stripe shape, in the blockshaped LPSO phase.

The white lines represent the grain boundaries with misorientation angles of $2-15^{\circ}$. These grain boundaries are described as low-angle grain boundaries (LAGBs). The grain boundaries with misorientation angles larger than $15^{\circ}$ are described as high-angle grain boundaries (HAGBs), which are represented by black lines. Moreover, the LAGBs are mainly distributed in the interior of the coarse grains. The HAGBs are mainly distributed at the grain boundaries of the original coarse grains and a small number of newly formed recrystallized grain boundaries. As can be seen from Figure 5, the colors of different coarse grains are different, that is, the orientations of the coarse grains are different. At the same time, inside the same grain, the colors of different areas are also different, which indicates that the CEE-AEC processes caused a rotation of the crystal. The black regions in the IPF maps mainly represent the LPSO phases, in which the EBSD system failed to recognize the LPSO phases due to the negligible confidence index (CI) caused by a lack of corresponding phase parameters. Due to a severe deformation near the original grain boundary and a high dislocation density, the fine grains formed at the grain boundary also exhibit random orientation distribution, which is mainly found at the trigeminal boundary.
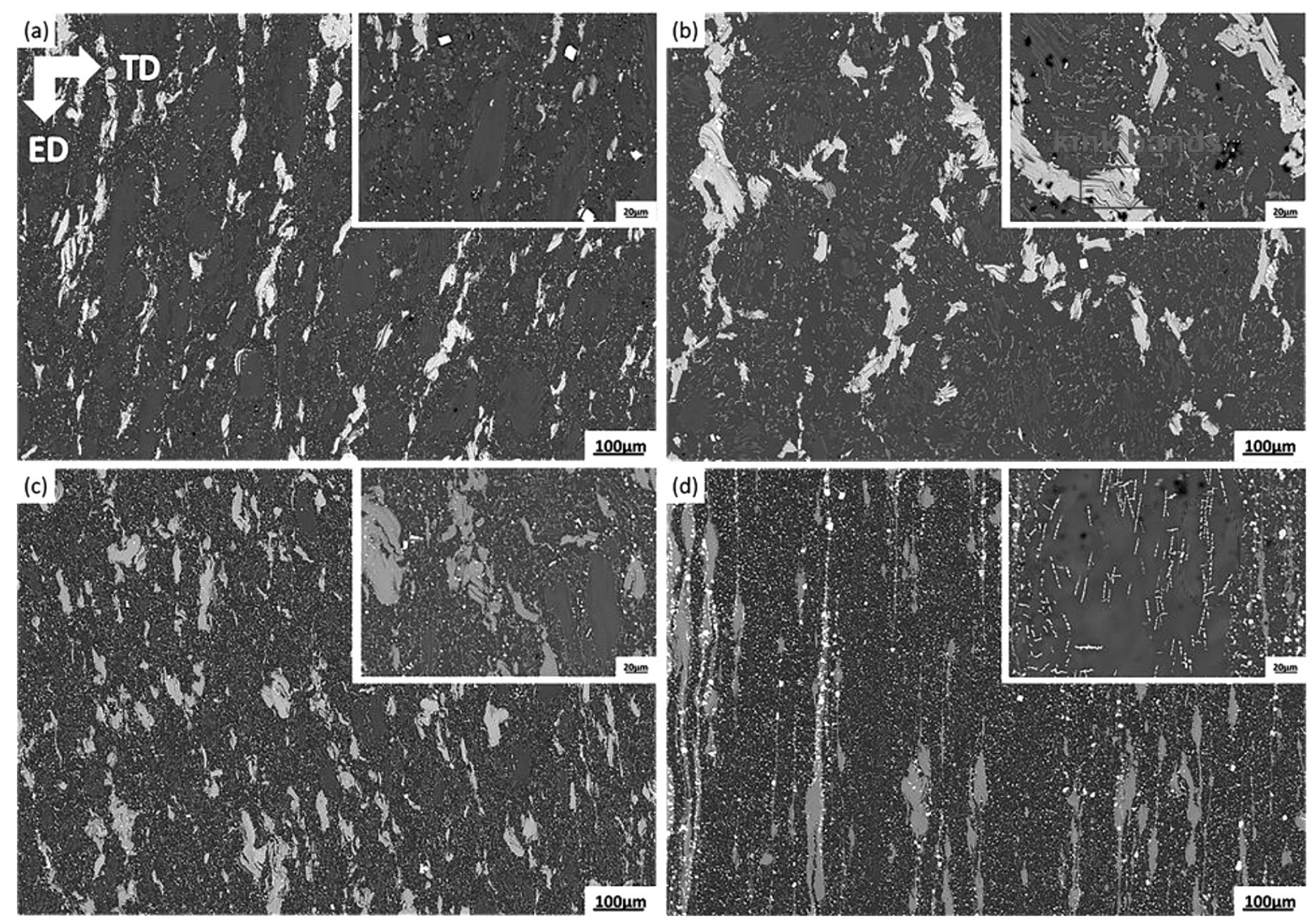

Figure 4: BSE images of the alloys after different processing passes: a) 1 pass, b) 2 passes, c) 3 passes, d) 4 passes 

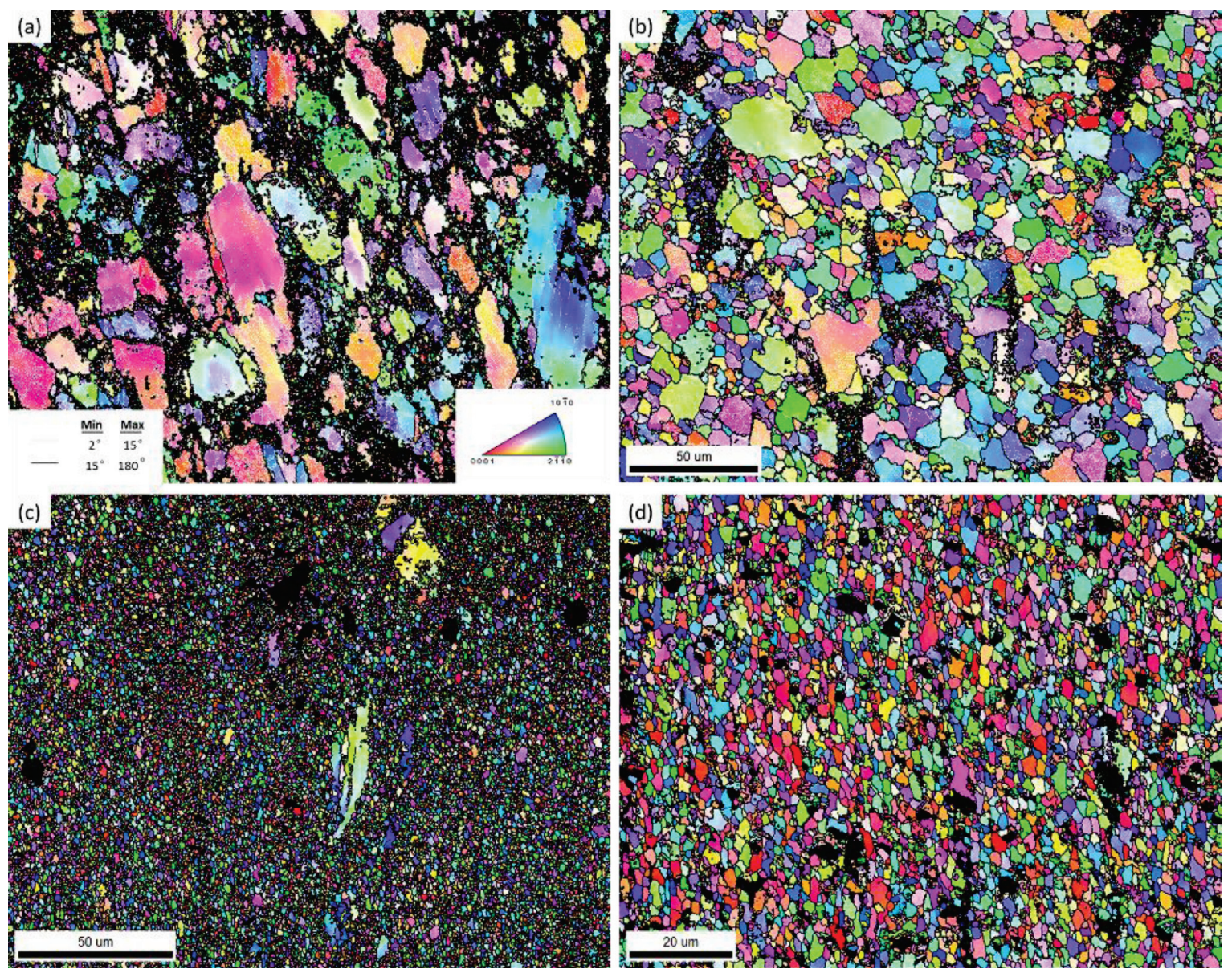

Figure 5: EBSD analysis of IPF maps after different processing passes: a) 1 pass,b) 2 passes, c) 3 passes, d) 4 passes

As the number of the CEE-AEC passes increases, although the recrystallization volume fraction increases significantly after three passes, there are still a few residual coarse grains. After four passes of the CEE-AEC process, the fine DRXed grains replace the original deformed grains, and the microstructure has a uniform and randomly fine-grained structure. After one CEE-AEC pass, the proportion of the LAGBs accounts for $54 \%$ of the total grain boundaries. And because of a low accumulation of strain, a large number of coarse primary grains and a small amount of DRX grains are the main constituents, dominated by discontinuous dynamic recrystallization (DDRX, which is characterized by the bulge-and-necklace structure). After three CEE-AEC passes, the proportion of the HAGBs gradually increases and the LAGBs gradually change into HAGBs.

The formation of uniform and small equiaxed grains has an obvious grain-refining effect, which is characterized by CDRX (it is also revealed by intense color grading and the LAGBs observed around the boundaries of most of the deformed particles in Figure 5). With the increasing number of the CEE-AEC passes, the NF of DRXed grains increases continuously from $34 \%$ to $67 \%$, and the DRXed grain size decreases from $13 \mu \mathrm{m}$
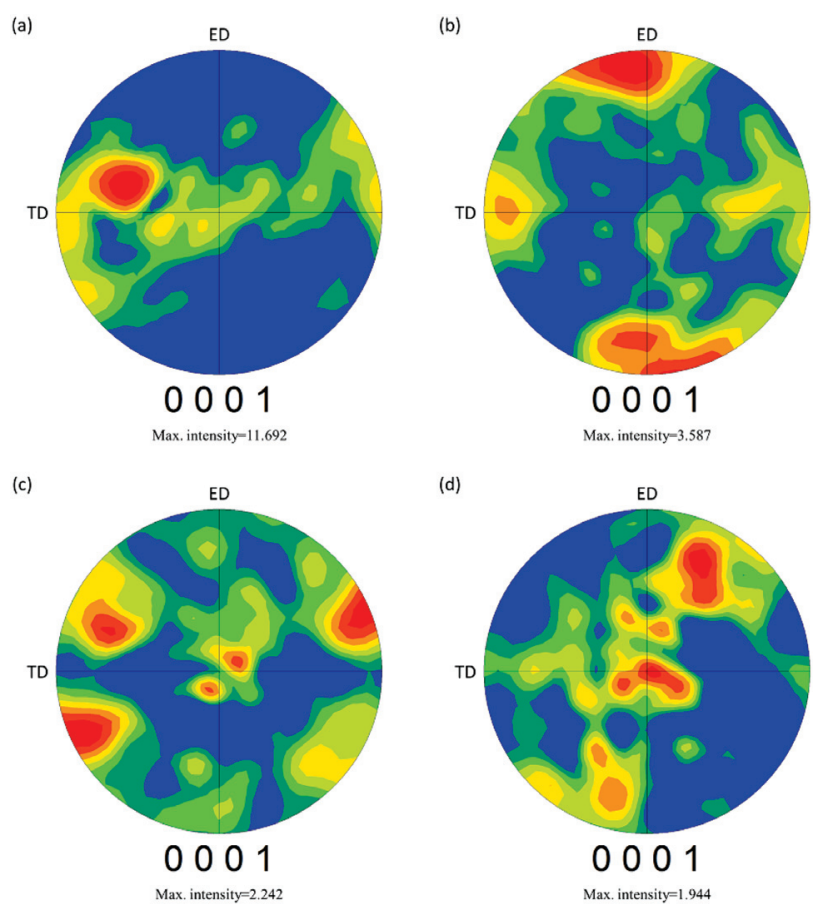

Figure 6: (0001) pole figures of the ED-TD plane of the Mg-13Gd-4Y-2Zn-0.5Zr alloy after different processing passes: a) 1 pass, b) 2 passes, c) 3 passes, d) 4 passes 
to $1.4 \mu \mathrm{m}$ after three CEE-AEC passes, while it increases to $1.6 \mu \mathrm{m}$ after an additional pass. In the CEE-AEC process, grain refinement is mainly derived from the fracture of coarse grains and the occurrence of DRX at the original grain boundaries. ${ }^{16}$ The change in the cumulative strain affects the progress of DRX. When the strain accumulates to a certain extent, it will lead to the occurrence of DRX. ${ }^{20}$ Therefore, after four passes of the CEE-AEC process, the strain is sufficient to lead to a homogeneous microstructure. DDRX may operate near the interdendritic LPSO phases via the particle-stimulated nucleation (PSN) mechanism. As the CEE-AEC passes continue to increase (i.e., cause an accumulated strain), DRX induces the conversion of the LAGBs into HAGBs via the CDRX mechanism. This experiment uses a multi-pass process at the cooling temperature. On the other hand, at higher temperatures, we see bulging of the original grain boundaries and subgrain growth, while DRX and new grains are formed at the original grain boundaries.

\subsection{Texture development}

The texture type after different passes was determined using the EBSD data. Figure 4 depicts the $\{0001\}$ pole figures of the ED-TD plane of the alloys after different processing passes. With the increasing CEE-AEC passes, the basal planes tend to change periodically. Therefore, the initial intense texture becomes so disintegrated that the basal poles are distributed more randomly and the maximum texture intensity declines gradually from 11.692 to 1.944 as the CEE-AEC passes increase from 1-4 passes, as shown in Figure 4, which is attributed to the texture weakening caused by an addition of the Gd and Y elements. A strong basal texture appeares in the alloy after the first pass. This type of texture is not the same as the typical base texture of the alloy after compression and extrusion. It was reported that the $\{0001\}$ plane is perpendicular to the compression-axis direction after compression ${ }^{21}$ and parallel to the extrusion-axis direction after extrusion. ${ }^{22}$ Due to the alternation between the axial and radial directions during a deformation process, most of the $\{0001\}$ base planes are deflected by $45^{\circ}$ in the direction of extrusion..$^{23}$ This new texture is similar to the texture appearing after the reciprocating extrusion of wrought magnesium alloy reported in reference, ${ }^{24}$ but in this paper, the CEE-AEC alloy has a lower maximum intensity of the texture. For a hot-deformed magnesium alloy, the DRX grains exhibit a random grain orientation, which offsets the deformation texture of the non-DRX grains and plays an important role in weakening the grain texture. ${ }^{25}$ The precipitated particles hinder the grain rotation, thus also contributing to the weakening of the texture.

The basal-texture weakening during asymmetric rolling is due to the asymmetric shear strain formed. ${ }^{26} \mathrm{In}$ the present study, the results indicate that the introduction of asymmetric deformation is very effective in the weakening of the basal texture during the extrusion.
L. L. Chang et al. ${ }^{27}$ show that the maximum asymmetric-shear deformation varies between different locations due to asymmetric extrusion, resulting in the rotation of the basal texture towards the extrusion direction. Compared with the previous experimental result for the texture evolution, this study does not state that the basal textures weaken and become scattered throughout the thickness due to asymmetric extrusion. It should be noted that the maximum basal-pole intensities are closely related to the average grain sizes of the samples. The maximum basal-pole intensities gradually decrease with the reducing average grain size of the AZ31 sheet after asymmetric porthole-die extrusion. ${ }^{28}$ Similar phenomena are found in this study; therefore, it is better at explaining the fact that the weakening of a basal texture may be mainly associated with the level of dynamic recrystallization during the deformation.

\section{CONCLUSIONS}

The grain refinement and a large number of precipitated phases were caused by the CEE-AEC process. The grain size decreased to $1.4 \mu \mathrm{m}$ from the initial value of $24 \mu \mathrm{m}$ after three CEE-AEC passes,but after four passes, the it increased slightly, to $1.6 \mu \mathrm{m}$.

With the increasing number of the CEE-AEC processing passes, the NF of LAGBs continued to decrease and the average misorientation increased due to the enhanced recrystallization process. The NFs of the LAGBs and HAGBs were mainly determined by the degree of DRX during CEE-AEC.

The basal texture was weakened after 4 passes and the shear strain led to the rotation by an angel of $45^{\circ}$. After 4 passes of CEE-AEC, the texture intensity of the alloy was reduced from 11.692 to 1.944 .

\section{Acknowledgment}

This research was funded through the Natural Science Foundation of China under grant No. 51675492, Natural Science Foundation of the Shanxi Province under grant No. 201801D121106, Key R\&D Program of the Shanxi Province (International Cooperation) under No. 201903D421036, and Scientific and Technological Innovation Programs of Higher Education Institutions in Shanxi under No. 2018002.

\section{REFERENCES}

${ }^{1}$ L. Tang, Y. Zhao, R. K. Islamgaliev, C. Y. A. Tsao, R. Z. Valiev, E. J. Lavernia, Y. T. Zhu, Enhanced strength and ductility of AZ80 Mg alloys by spray forming and ECAP, Materials Science and Engineering: A, 670 (2016), 280-291, doi:10.1016/j.msea.2016. 06.031

${ }^{2}$ Y. Yuan, A. Ma, J. Jiang, F. Lu, W. Jian, D. Song, Y. T. Zhu, Optimizing the strength and ductility of AZ91 Mg alloy by ECAP and subsequent aging, Materials Science and Engineering: A, 588 (2013), 329-334, doi:10.1016/j.msea.2013.09.052 
${ }^{3}$ L. Zhang, B. Ye, W. Liao, H. Zhou, W. Guo, Q. Wang, H. Jiang, W. Ding, Microstructure evolution and mechanical properties of AZ91D magnesium alloy processed by repetitive upsetting, Materials Science and Engineering: A, 641 (2015), 62-70, doi:10.1016/j.msea. 2015.06.040

${ }^{4}$ S. Sepahi-Boroujeni, A. Sepahi-Boroujeni, Improvements in microstructure and mechanical properties of AZ80 magnesium alloy by means of an efficient, novel severe plastic deformation process, Journal of Manufacturing Processes, 24 (2016), 71-77, doi:10.1016/ j.jmapro.2016.07.007

${ }^{5}$ N. Pardis, C. Chen, M. Shahbaz, R. Ebrahimi, L. S. Toth, Development of new routes of severe plastic deformation through cyclic expansion-extrusion process, Materials Science and Engineering: A, 613 (2014), 357-364, doi:10.1016/j.msea.2014.06.074

${ }^{6}$ Y. Estrin, A. Vinogradov, Extreme grain refinement by severe plastic deformation: A wealth of challenging science, Acta Materialia, 61 (2013) 3, 782-817, doi:10.1016/j.actamat.2012.10.038

${ }^{7}$ R. Z. Valiev, Y. Estrin, Z. Horita, T. G. Langdon, M. J. Zehetbauer, Y. T. Zhu, Producing bulk ultrafine-grained materials by severe plastic deformation, JOM, 58 (2006) 4, 33-39, doi:10.1007/s11837-0060213-7, PubMed PMID: WOS:000236824700005

${ }^{8}$ N. Pardis, B. Talebanpour, R. Ebrahimi, S. Zomorodian, Cyclic expansion-extrusion (CEE): A modified counterpart of cyclic extrusion-compression (CEC), Materials Science and Engineering: A, 528 (2011) 25-26, 7537-7540, doi:10.1016/j.msea.2011.06.059

${ }^{9}$ Y. Xue, Z. Yang, B. Bai, Z. Zhang, Y. Du, L. Ren, Effect of different cyclic expansion-extrusion processes on microstructure and mechanical properties of AZ80 magnesium alloy, Advances in Mechanical Engineering, 9 (2017) 4, doi:10.1177/1687814017696657

${ }^{10} \mathrm{~S}$. Sepahi-Boroujeni, F. Fereshteh-Saniee, The influences of the expansion equal channel angular extrusion operation on the strength and ductility of AZ80 magnesium alloy, Materials Science and Engineering: A, 636 (2015), 249-253, doi:10.1016/j.msea.2015.03.073

${ }^{11}$ S. M. Masoudpanah, R. Mahmudi, The microstructure, tensile, and shear deformation behavior of an AZ31 magnesium alloy after extrusion and equal channel angular pressing, Materials \& Design, 31 (2010) 7, 3512-3517, doi:10.1016/j.matdes.2010.02.018.

${ }^{12}$ F. Guo, D.-f. Zhang, X.-s. Yang, L.-y. Jiang, F.-s. Pan, Microstructure and texture evolution of AZ31 magnesium alloy during large strain hot rolling, Transactions of Nonferrous Metals Society of China, 25 (2015) 1, 14-21, doi:10.1016/s1003-6326(15)63573-7

${ }^{13}$ M. Kaseem, B. K. Chung, H. W. Yang, K. Hamad, Y. G. Ko, Effect of Deformation Temperature on Microstructure and Mechanical Properties of AZ31 Mg Alloy Processed by Differential-Speed Rolling, Journal of Materials Science \& Technology, 31 (2015) 5, 498-503, doi:10.1016/j.jmst.2014.08.016

${ }^{14}$ A. Babaei, M. M. Mashhadi, H. Jafarzadeh, Tube cyclic expansion-extrusion (TCEE) as a novel severe plastic deformation method for cylindrical tubes, Journal of Materials Science, 49 (2014) 8, 3158-3165, doi:10.1007/s10853-014-8017-6

${ }^{15}$ N. Pardis, C. Chen, M. Shahbaz, R. Ebrahimi, L. S. Toth, Development of new routes of severe plastic deformation through cyclic expansion-extrusion process, Materials Science and Engineering: A, 613 (2014), 357-364, doi:10.1016/j.msea.2014.06.074
${ }^{16}$ G. Zhang, Z. Zhang, X. Li, Z. Yan, X. Che, J. Yu, Y. Meng, Effects of repetitive upsetting-extrusion parameters on microstructure and texture evolution of $\mathrm{Mg}-\mathrm{Gd}-\mathrm{Y}-\mathrm{Zn}-\mathrm{Zr}$ alloy, Journal of Alloys and Compounds, 790 (2019), 48-57, doi:10.1016/j.jallcom.2019.03.207

${ }^{17}$ J. Wang, J. Meng, D. Zhang, D. Tang, Effect of Y for enhanced age hardening response and mechanical properties of $\mathrm{Mg}-\mathrm{Gd}-\mathrm{Y}-\mathrm{Zr}$ alloys, Materials Science and Engineering: A, 456 (2007) 1-2, 78-84, doi:10.1016/j.msea.2006.11.096

${ }^{18}$ X. Zhou, C. Liu, Y. Gao, S. Jiang, W. Liu, L. Lu, Microstructure and mechanical properties of extruded Mg-Gd-Y-Zn-Zr alloys filled with intragranular LPSO phases, Materials Characterization, 135 (2018), 76-83, doi:10.1016/j.matchar.2017.11.027

${ }^{19}$ C. Xu, J. P. Pan, T. Nakata, X. G. Qiao, Y. Q. Chi, M. Y. Zheng, S. Kamado, Hot compression deformation behavior of Mg-9Gd2.9Y-1.9Zn-0.4Zr-0.2Ca (wt \%) alloy, Materials Characterization, 124 (2017), 40-49, doi:10.1016/j.matchar.2016.11.036

${ }^{20}$ Y. P. Wu, X. M. Zhang, Y. L. Deng, C. P. Tang, Y. Y. Zhong, Effect of compression conditions on the microstructure and texture of a Mg-RE alloy, Materials Science and Engineering: A, 644 (2015), 152-158, doi:10.1016/j.msea.2015.07.064

${ }^{21}$ D. K. Xu, L. Liu, Y. B. Xu, E. H. Han, Effect of microstructure and texture on the mechanical properties of the as-extruded $\mathrm{Mg}-\mathrm{Zn}-\mathrm{Y}-\mathrm{Zr}$ alloys, Materials Science and Engineering: A, 443 (2007) 1-2, 248-256, doi:10.1016/j.msea.2006.08.037

${ }^{22}$ Y. Du, Z. Zhang, G. Zhang, Z. Yan, J. Yu, Grain Refinement and Texture Evolution of Mg-Gd-Y-Zn-Zr Alloy Processed by Repetitive Usetting-Extrusion at Decreasing Temperature, Rare Metal Materials and Engineering, 47 (2018) 5, 1422-1428, PubMed PMID: WOS:000434366800015

${ }^{23}$ J. Lin, Q. Wang, Y. Chen, X. Cui, Influence of Grain Refinement and Texture Evolution on the Yield Strength of Mg Alloy Processed by Cyclic Extrusion and Compression, Materials Transactions, 55 (2014) 1, 120-122, doi:10.2320/matertrans.MA201306

${ }^{24}$ T. Al-Samman, G. Gottstein, Dynamic recrystallization during high temperature deformation of magnesium, Materials Science and Engineering: A, 490 (2008) 1-2, 411-420, doi:10.1016/j.msea.2008. 02.004

${ }^{25}$ G. Garcés, M. Maeso, I. Todd, P. Pérez, P. Adeva, Deformation behaviour in rapidly solidified Mg97Y2Zn (at.\%) alloy, Journal of Alloys and Compounds, 432 (2007) 1-2, L10-L14, doi:10.1016/j.jallcom.2006.06.009

${ }^{26}$ W. J. Kim, J. B. Lee, W. Y. Kim, H. T. Jeong, H. G. Jeong, Microstructure and mechanical properties of $\mathrm{Mg}-\mathrm{Al}-\mathrm{Zn}$ alloy sheets severely deformed by asymmetrical rolling, Scripta Materialia, 56 (2007) 4, 309-312, doi:10.1016/j.scriptamat.2006.09.034

${ }^{27}$ L. L. Chang, Y. N. Wang, X. Zhao, J. C. Huang, Microstructure and mechanical properties in an AZ31 magnesium alloy sheet fabricated by asymmetric hot extrusion, Materials Science and Engineering: A, 496 (2008) 1-2, 512-516, doi:10.1016/j.msea.2008.06.015

${ }^{28}$ Q. Wang, J. Song, B. Jiang, A. Tang, Y. Chai, T. Yang, G. Huang, F. Pan, An investigation on microstructure, texture and formability of AZ31 sheet processed by asymmetric porthole die extrusion, Materials Science and Engineering: A, 720 (2018), 85-97, doi:10.1016/j.msea.2018.02.055 